\begin{abstract}
Iranica
Abstracta Iranica Revue bibliographique pour le domaine irano-aryen

Volume 32-33 | 2013

Comptes rendus des publications de 2009-2010
\end{abstract}

\title{
Florence Jullien (éd.). Le monachisme syriaque
}

\section{Christelle Jullien}

\section{(2) OpenEdition}

Journals

Édition électronique

URL : http://journals.openedition.org/abstractairanica/40846

DOI : 10.4000/abstractairanica.40846

ISSN : 1961-960X

Éditeur :

CNRS (UMR 7528 Mondes iraniens et indiens), Éditions de l'IFRI

Édition imprimée

Date de publication : 1 décembre 2013

ISSN : 0240-8910

\section{Référence électronique}

Christelle Jullien, «Florence Jullien (éd.). Le monachisme syriaque », Abstracta Iranica [En ligne], Volume 32-33 | 2013, document 331, mis en ligne le 01 juillet 2016, consulté le 26 septembre 2020. URL : http://journals.openedition.org/abstractairanica/40846; DOI : https://doi.org/10.4000/ abstractairanica.40846

Ce document a été généré automatiquement le 26 septembre 2020.

Tous droits réservés 


\title{
Florence Jullien (éd.). Le monachisme syriaque
}

\author{
Christelle Jullien
}

\section{RÉFÉRENCE}

Florence Jullien (éd.). Le monachisme syriaque. Paris, Geuthner, 2010, 335 p. (Études syriaques 7)

1 L'histoire des communautés syriaques, notamment en Iran, est intrinsèquement liée à celle du monachisme. Parmi les thématiques retenues des actes de cette table ronde : le Qeyama (proto-monachisme), les formes de la vie ascétique, le monachisme féminin, les controverses entre hiérarchie et moines, les réglementations, les productions manuscrites, l'épigraphie, avec une étude plus approfondie sur les monastères du Tur 'Abdin en Mésopotamie du Nord. Un ensemble de cartes, une bibliographie exhaustive sur les sources documentaires et une classification thématique des études concernant le monachisme sont extrêmement utiles et font de cet ouvrage un instrument de travail incontournable pour qui voudrait entreprendre des prospections sur cette question.

\section{AUTEURS}

\section{CHRISTELLE JULLIEN}

CNRS, Mondes iranien et indien, Paris 